\title{
Feasibility of Utilizing Waste Polyethylene Terephthalate as Replacement in Asphalt binder Mixture
}

\author{
Bashir.A. Almahdi ${ }^{1, *}$, Abobaker G. F. Ahmeda ${ }^{2}$, Ibrahim Adwan', Mohd Azizul Ladin ${ }^{3}$ \\ ${ }^{1}$ Department. of Civil Engineering, Universiti Kebangsaan Malaysia, Selangor, Malaysia; ibr598@ gmail.com \\ ${ }^{2}$ Department of Civil and Structural Engineering, Higher Institute of Science and Technology Aljufra (HIST), Sokna, \\ Libya; abgribi@gmail.com \\ ${ }^{3}$ Faculty of Engineering, Universiti Malaysia Sabah, Sabah, Malaysia; azizul@ums.edu.my \\ * Correspondence: bashiralmahdia@gmail.com
}

Manuscript received: 25-04-2021, revised: 27-04-2021, accepted: 29-04-2021.

\begin{abstract}
The feasibility of utilizing waste material for road construction is encouraging as it can decrease waste material harmful to the environment. Hence, a more sustainable method and a meticulous study of the available admixtures utilized to substitute standard asphalt binders with waste material must be conducted. However, there are several concerns and doubts about the real situation arising from the chemical and physical traits, as well as the mechanical performance issuing from the integration of waste material within the asphalt pavement to alleviate roads surface's permanent deformation. This investigation was carried out to study physical improvements made on ACW-14 bitumen by adding waste Polyethylene Terephthalate (PET) to serve as a partial replacement for bitumen content compared to normal, conventional 80/100 bitumen physical and rheological behavior. PET percentage added to the bitumen content was $10 \%, 8 \%, 6 \%, 4 \%$ and $2 \%$ of optimum bitumen content weight. The outcomes concluded that the best performance of bitumen on its density, VTM, VFB, flow, stability, and stiffness was achieved when 5.8\% of Optimum Modified-Bitumen Content using PET. All the results obtained have been compared according to JKR Standards results, and the conclusion has fulfilled these requirements.
\end{abstract}

Keywords: PET polymer, Recycling, asphalt mixtures, properties, waste materials.

\section{Introduction}

The widely common usage of asphalt concrete in road engineering is attributed to its superior qualities including ease of repair, low noise, seamlessness and pleasant driving comfortability [1]. Nowadays, the construction of asphalt pavement is most often carried out via conventional HMA technology. In this case, aggregates and bitumen are heated together at approximately $170^{\circ} \mathrm{C}$. The affecting of the prevailing maximum and minimum temperatures on the performance of bituminous materials and their mechanical properties can vary significantly with the temperature changes [2]. The feasibility of engorging waste material used in the highways construction industry plays a leading role worldwide as green investment movement [3,4]. The use of waste materials in the road construction field is an innovative recycling approach [4]. Therefore, recently, several types of research have been carried out to examine the validity of the usage of alternative waste material like (reclaimed asphalt pavement, waste cooking oil, plastic, geopolymer, and scrap tires etc.) in the hot-mix asphalt (HMA) pavement, which could minimize the deterioration of the roads [6-10]. Utilizing recycled materials as an eco-friendly substitute is divided into three major classifications: performance, economic, and environmental benefits $[11,12]$.

Plastics are an integral part of our lives. However, the rise in globally accumulated plastic waste requires proper end-of-life management. Plastics make up a significant composition of packaging containers (such as cups, bottles, etc.), durables (such as building materials, furniture, etc.) and disposable consumables (e.g. medical devices and kits). The global annual consumption of plastic material in 2002 alone was at 204 million tons and grew to a staggering 300 million tons in the year 2013 [7]. In addition, the PET waste that makes up $55-60 \%$ of plastic bottles to modify the mixture of conventional asphalt, will aid the removal of post-consumer plastic wastes from the waste stream. It would also improve the traits of ordinary asphalt mixture. The recycling of PET waste to serve as a modified asphalt mixture to construct flexible pavements can potentially remove plastic waste from waste streams. This is especially the case since $92.3 \%$ of paved roads worldwide are made up of flexible pavements. Some of the plastic types that may be utilized in asphalt mixture include High-Density Polyethylene (HDPE), Polystyrene (PS), Polyvinyl Acetate (PVA), Polyethylene Terephthalate (PET), Low- 
Density Polyethylene (LDPE), Polyvinyl Chloride (PVC), and Polypropylene (PP). The economic benefit of integrating PET into binders was found in this study to promote great savings in terms of cost of materials [8]. The properties of PET polymer include low permeability to gas, chemically and thermally stable, ease of handling, durable and robust [9]. The recycled plastic does not release any toxic gas during the softening process. Waste Polyethylene terephthalate (PET) makes up about $60 \%$ of the plastic waste and is the primary plastic waste component. The addition of PET as a modifier in asphalt binder and mixtures, treating aggregates against moisture, can increase the mixture's strength [16,17]. Thus, incorporating plastic wastes into bituminous asphaltic concrete (BAC) permits the improvement of flexible pavement performance and reduction of environmental pollution.

In addition, the use of 1.18-mm PET size enabled the enhancement of stone mastic asphalt's rutting resistance and stiffness, generated less binder drain down, improved the balance of the ecosystem, contributes to financial savings, and conserves natural energy and resources [18-20]. Numerous researchers studied how to improve waste materials such as plastic waste in bitumen modifiers for hot asphalt mixture properties and factors affecting pavement damage. A summary of the usage of waste plastic within the asphalt mixture is shown in Table 1 . This study aims to provide an environmentally friendly way of utilizing PET recycle plastic bottle waste in asphalt mixture that is utilized as surface and binder courses within the construction of roads.

Table 1. Summary of the use of the waste plastic in the asphalt mixture.

\begin{tabular}{|c|c|c|c|c|c|}
\hline Materials used & $\begin{array}{l}\text { Percenta } \\
\text { ge }\end{array}$ & Size & $\begin{array}{c}\text { Blending } \\
\text { details }\end{array}$ & Results & Ref. \\
\hline $\begin{array}{l}\text { Low-density } \\
\text { polyethylene } \\
\text { bags, and } \\
\text { Polyvinyl } \\
\text { chloride (PVC) }\end{array}$ & $\begin{array}{lr}2.5, & 5, \\
7.5, & 10, \\
12.5, & 15, \\
17.5, & \text { and } \\
20 \% & \end{array}$ & $2-3 \mathrm{~mm}$ & - & $\begin{array}{l}-7.5 \% \text { PVC and } 10 \% \text { polyethylene by } \\
\text { weight of asphalt level can construct hot } \\
\text { mix asphalt. } \\
-7.5 \% \text { PVC and } 10 \% \text { polyethylene by } \\
\text { weight of asphalt level could enhance } \\
\text { the asphalt's overall performance in } \\
\text { terms of stability and stiffness. }\end{array}$ & [21] \\
\hline $\begin{array}{l}\text { Polyethylene } \\
\text { carry bags }\end{array}$ & $1.5 \%$ & $2.36 \mathrm{~mm}$ & $\begin{array}{l}\text { - Wet method } \\
-170-180{ }^{\circ} \mathrm{C} \\
-20-30 \mathrm{~min}\end{array}$ & $\begin{array}{l}\text { - Using plastic waste in asphalt mixture } \\
\text { will help reduce bitumen by around } \\
10 \% \text { and grow the asphalt mixture's } \\
\text { overall performance. }\end{array}$ & [22] \\
\hline $\begin{array}{l}\text { Waste plastic } \\
\text { bottles (PET) }\end{array}$ & $\begin{array}{l}2,4,6,8, \\
10 \%\end{array}$ & $\leq 1.18 \mathrm{~mm}$ & -Dry method & $\begin{array}{l}\text { - The asphalt mixtures' fatigue behavior } \\
\text { will be effectively influenced by the } \\
\text { incorporation of PET within the range } \\
\text { of } 2-10 \% \text { by weight of asphalt. } \\
\text { - PET had an identical impact on the } \\
\text { resilient modulus and indirect tensile } \\
\text { strength ITS. }\end{array}$ & [23] \\
\hline $\begin{array}{l}\text { Waste } \\
\text { Polyethylene } \\
\text { Terephthalate } \\
\text { (PET) }\end{array}$ & $\begin{array}{l}0,0.1, \\
0.2, \quad 0.3, \\
0.4 \%, \\
0.5, \\
0.6 \%, \\
0.7, \quad 0.8, \\
0.9 \quad \text { and } \\
1 \%\end{array}$ & $3 \mathrm{~mm}$ & -Dry method & $\begin{array}{l}\text { - The indirect tensile strength levels } \\
\text { dropped with the incorporation of PET, } \\
\text { and the use of greater levels of PET } \\
\text { caused lower tensile strength values } \\
\text { TSR. } \\
\text {-It can thus be concluded that PET } \\
\text { modified asphalt mixture possessed } \\
\text { distinct rutting behavior under dynamic } \\
\text { and static loadings. }\end{array}$ & [24] \\
\hline $\begin{array}{l}\text { Waste } \\
\text { Polyethylene } \\
\text { Terephthalate } \\
\text { (PET) }\end{array}$ & $0-1 \%$ & $\leq 2.36 \mathrm{~mm}$ & $\begin{array}{l}\text {-Dry method } \\
\text {-Treatment } \\
\text { before added } \\
\text { to the mixture } \\
\left(60^{\circ} \mathrm{C} \text { for } 30\right. \\
\text { min })\end{array}$ & $\begin{array}{l}\text { - Greater stability for the modified } \\
\text { asphalt mixtures was obtained by } \\
\text { asphalt binder level lower than } 5.5 \% \\
\text { and with of } 0.2-0.8 \% \text { PET. } \\
\text { - } 0.18 \% \text { of PET level and } 5.88 \% \text { of } \\
\text { asphalt content were the best values in } \\
\text { order to meet the design requirements } \\
\text { of Marshall mix. }\end{array}$ & [25] \\
\hline Waste plastic & $\begin{array}{l}1.5,3.0 \\
4.5 \text { and } \\
6.0 \%\end{array}$ & $2 \mathrm{~mm}$ & $\begin{array}{l}\text { - Wet method } \\
-170-175^{\circ} \mathrm{C} \\
-1200-1500 \\
\text { rpm } \\
-60 \mathrm{~min}\end{array}$ & $\begin{array}{l}\text { - The greater percentage of plastic waste } \\
\text { gives a rutting factor to the higher } \\
G^{*} / \sin \delta \text {. } \\
\text { - } 6 \% \text { of waste plastic could make the } \\
\text { pavement capable of resisting the }\end{array}$ & $\begin{array}{l}{[26]} \\
{[17]}\end{array}$ \\
\hline
\end{tabular}


KBES 2021, 2, 1

\begin{tabular}{|c|c|c|c|c|c|}
\hline & & & & $\begin{array}{l}\text { permanent deformation at high } \\
\text { temperatures. }\end{array}$ & \\
\hline $\begin{array}{l}\text { Polyethylene } \\
\text { Terephthalate } \\
(\text { PET) }\end{array}$ & $\begin{array}{l}2 \%, 4 \%, \\
6 \%, 8 \%, \\
\text { and } 10 \%\end{array}$ & $\leq 1.18 \mathrm{~mm}$ & $\begin{array}{l}\text {-Dry method } \\
-165^{\circ} \mathrm{C} \\
-2 \mathrm{~min}\end{array}$ & $\begin{array}{l}\text { - The addition of PET to the mixture } \\
\text { reduces the mixture's bulk specific } \\
\text { gravity while raising the air voids. } \\
\text { - The greatest degree of stability occurs } \\
\text { at } 6 \% \text { of PET by the weight of bitumen. }\end{array}$ & {$[27]$} \\
\hline $\begin{array}{l}\text { Polyethylene } \\
\text { Terephthalate } \\
(\text { PET) }\end{array}$ & $\begin{array}{l}2 \%, 4 \%, \\
6 \%, 8 \%, \\
\text { and } 10 \%\end{array}$ & $\leq 1.18 \mathrm{~mm}$ & $\begin{array}{l}\text {-Dry method } \\
-165^{\circ} \mathrm{C} \\
-2 \mathrm{~min}\end{array}$ & $\begin{array}{l}\text { - In comparison with the conventional } \\
\text { mixture. the resilient modulus value of } \\
\text { the SMA mixture was enhanced by } 16 \% \\
\text { by using } 6 \% \text { PET. } \\
\text { - The mix with } 4 \% \text { PET produced the } \\
\text { lowest rut depth at } 29 \% \text { in comparison } \\
\text { with the conventional mix. } \\
\text { - All TSR values were above } 70 \% \text {, } \\
\text { which indicates that all PET } \\
\text { modifications could improve the } \\
\text { asphalt mixture in terms of moisture } \\
\text { damage. }\end{array}$ & [28] \\
\hline $\begin{array}{l}\text { Polyethylene } \\
\text { Terephthalate } \\
\text { (PET) }\end{array}$ & $\begin{array}{ll}5 & \text { and } \\
25 \% & \end{array}$ & $2.36-1.18 \mathrm{~mm}$ & $\begin{array}{l}\text { - Dry } \\
\text { method }\end{array}$ & $\begin{array}{l}\text { - Resistance of asphalt's permanent } \\
\text { deformation appeared to be enabled by } \\
20 \% \text { PET modified asphalt mixture. } \\
\text { - Increased PET contents lead to a lower } \\
\text { stiffness of the asphalt mixture. }\end{array}$ & [29] \\
\hline $\begin{array}{l}\text { Low-density } \\
\text { polyethylene }\end{array}$ & $6 \%$ & - & $\begin{array}{l}\text {-Wet method } \\
-150{ }^{\circ} \mathrm{C} \\
-120 \mathrm{~min} \\
-440 \mathrm{rpm}\end{array}$ & $\begin{array}{l}\text { - The fatigue at low shear strain levels } \\
\text { may be enhanced via the incorporation } \\
\text { of PE to the asphalt binder. } \\
\text { - A suitable alternative for growing } \\
\text { fatigue and rutting resistance is } \\
\text { adopting asphalt binder modification } \\
\text { with PE. }\end{array}$ & [30] \\
\hline
\end{tabular}

\section{Materials and method}

The materials used in the Marshall mix design are aggregates (Fine \& Coarse Aggregate), bitumen (80/100), and PET obtained from IUKL Laboratory. Next, the waste PET is cleaned and washed. A plastic shredding machine is then used to shred the waste into a maximum size of $2 \mathrm{~mm}$. The dry process was done for asphalt mixture tests, while the wet process was done for the asphalt binder tests. The waste PET was directly integrated within the asphalt mixture during the mixing stage for the Dry process [19]. For the Wet process, the virgin bitumen was subjected to heat to reach a temperature not exceeding $150{ }^{\circ} \mathrm{C}$. Subsequently, a small quantity of PET was added during the 120 minutes of mix time. The mixing was carried out at a sheer mix rate of 440rpm with a constant temperature of $150{ }^{\circ} \mathrm{C}$ [21].

The Polyethylene Terephthalate (PET) added to asphalt mixture with percentages of 2\%, 4\%, 6\%, $8 \%$, $10 \%$. The HMA mixture specifications dictate that aggregate particles must fall within a specific range of sizes, with each size integrated based on available amounts. The gradation of the AC14 mix utilized is shown in Table 2.

Table 2. Gradation of aggregate.

\begin{tabular}{|c|c|c|}
\hline Sieve Size & Percentage (\%) & Weight (g) \\
\hline $14.0 \mathrm{~mm}$ & $30 \%$ & $334.5 \mathrm{~g}$ \\
\hline $10.0 \mathrm{~mm}$ & $17 \%$ & $189.6 \mathrm{~g}$ \\
\hline Q. Dust & $51 \%$ & $568.7 \mathrm{~g}$ \\
\hline Cement & $2 \%$ & $22.3 \mathrm{~g}$ \\
\hline Total & $100 \%$ & $1115.0 \mathrm{~g}$ \\
\hline
\end{tabular}


Similar to other mix design approaches, several trial aggregates-asphalt binder blends are utilised in the Marshall method. Each has different asphalt binder content and usually, five blends with three samples each for a total of 15 specimens. Next, an optimum asphalt binder content may be chosen by assessing the performance of each trial blend. After determining the control bitumen's optimum bitumen content (OBC), a total of 15 samples will be prepared by mixing $2 \%, 4 \%, 6 \%, 8 \%$ and $10 \%$ of Polyethylene Terephthalate (PET) polymer by optimum bitumen content weight. Table 3 indicates the method used in adding PET polymer. The optimum bitumen content was determined to be 5.33\%; thus, which is means 63 grams of control bitumen.

Table 3. Adding PET polymer method.

\begin{tabular}{|c|c|c|}
\hline Percentage of PET & Weight of PET $(\mathbf{g})$ & Weight of Bitumen $(\mathbf{g})$ \\
\hline $2 \%$ & 1.26 & 61.74 \\
\hline $4 \%$ & 2.52 & 60.48 \\
\hline $6 \%$ & 3.78 & 59.22 \\
\hline $8 \%$ & 5.04 & 57.96 \\
\hline $10 \%$ & 6.30 & 56.7 \\
\hline
\end{tabular}

\section{Modeling results}

\subsection{Physical properties}

The result of control and modified bitumen's softening and penetration are displayed in Table 4. Thus, the addition of PET polymer to bitumen has improved its bitumen to overcome softening at high temperatures. The results showed that at $10 \%$ PET, Polymer addition had raised the softening point of bitumen to $79{ }^{\circ} \mathrm{C}$ as shown in Table 4. However, the penetration values decreased with increased percentages of the PET. Thus, the PET addition could increase the hardness of the bitumen.

Table 4. Penetration and Softening Point results for controlled and modified samples.

\begin{tabular}{|c|c|c|}
\hline Sample & PEN $(\mathbf{m m})$ & Temperature $\left({ }^{\circ} \mathbf{C}\right)$ \\
\hline Control Sample & 81.0 & 51 \\
\hline Bitumen $+2 \%($ PET) & 77.2 & 56 \\
\hline Bitumen $+4 \%($ PET) & 71.3 & 59 \\
\hline Bitumen $+6 \%($ PET) & 65 & 63 \\
\hline Bitumen $+8 \%($ PET) & 57 & 71 \\
\hline Bitumen $+10 \%($ PET) & 48 & 79 \\
\hline
\end{tabular}

\subsection{Marshall properties for Control and modified asphalt}

\subsubsection{Determining Optimum Bitumen Content}

Following the specifications, the AC14's optimum bitumen content (OBC) was assessed via utilisation of bitumen levels of $6 \%, 5.5 \%, 5.0 \%, 4.5 \%$ and $4 \%$. The information gathered were studied via Marshall traits. As shown in Table 5, the Marshall Test outcome for ACW-14 highlights the results for OBC at 5.33\% and OBC at $5.32667 \%$. Following Optimum bitumen content for control sample weight as per JKR Specification, the ACW 14's optimum modified bitumen content (OBC) was set by utilizing bitumen levels of 10\%, 8\%, 6\%, 4\% and $2 \%$. Marshall properties were used to assess gathered data. The stability value obtained at optimum bitumen content of $5.33 \%$ was $3,400 \mathrm{~N} / \mathrm{mm}$. The stability value obtained at optimum modified-bitumen content of $5.8 \%$ of PET Polymer was $4,000 \mathrm{~N} / \mathrm{mm}$.

Table 5. Marshal test result for control bitumen.

\begin{tabular}{|c|c|c|c|c|c|c|}
\hline Bitumen content $\mathbf{( \% )}$ & $\begin{array}{c}\text { Density } \\
\left(\mathbf{g} / \mathbf{c m}^{\mathbf{3}}\right)\end{array}$ & Stability (N) & VTM $(\boldsymbol{\%})$ & VFB (\%) & $\begin{array}{c}\text { Flow } \\
(\mathbf{m m})\end{array}$ & $\begin{array}{c}\text { Stiffness } \\
(\mathbf{N} / \mathbf{m m})\end{array}$ \\
\hline 4.0 & 2.28 & 11705.64 & 7.26 & 55.23 & 3.16 & 3730.13 \\
\hline 4.5 & 2.28 & 12879.54 & 6.57 & 60.53 & 3.13 & 4119.43 \\
\hline 5.0 & 2.3 & 14059.68 & 5.16 & 68.6 & 3.95 & 3561.7 \\
\hline
\end{tabular}




\begin{tabular}{|l|l|l|l|l|l|l|}
\hline 5.5 & 2.31 & 12814.26 & 3.97 & 75.87 & 4.1 & 3134.08 \\
\hline 6.0 & 2.29 & 8341.41 & 4.06 & 76.88 & 4.32 & 1933.36 \\
\hline
\end{tabular}

\subsubsection{Density}

This study showed that maximum density was achieved at $5.0 \%$. The highest density achieved was $2.30 \mathrm{~g} / \mathrm{cm} 3$. Figure 1 shows the graph of bulk density versus bitumen content for the control sample. Bulk density is considered one of the elements to calculate the optimum bitumen content. The peak of the curve is considered the maximum density of the bitumen mixes. The mix's density value rises with rising levels of bitumen until a maximum point. This study showed that maximum bulk density for PET modified bitumen was achieved at $6.0 \%$ of Polyethylene Terephthalate (PET) polymer addition. The highest density achieved was $2.31 \mathrm{~g} / \mathrm{cm} 3$.

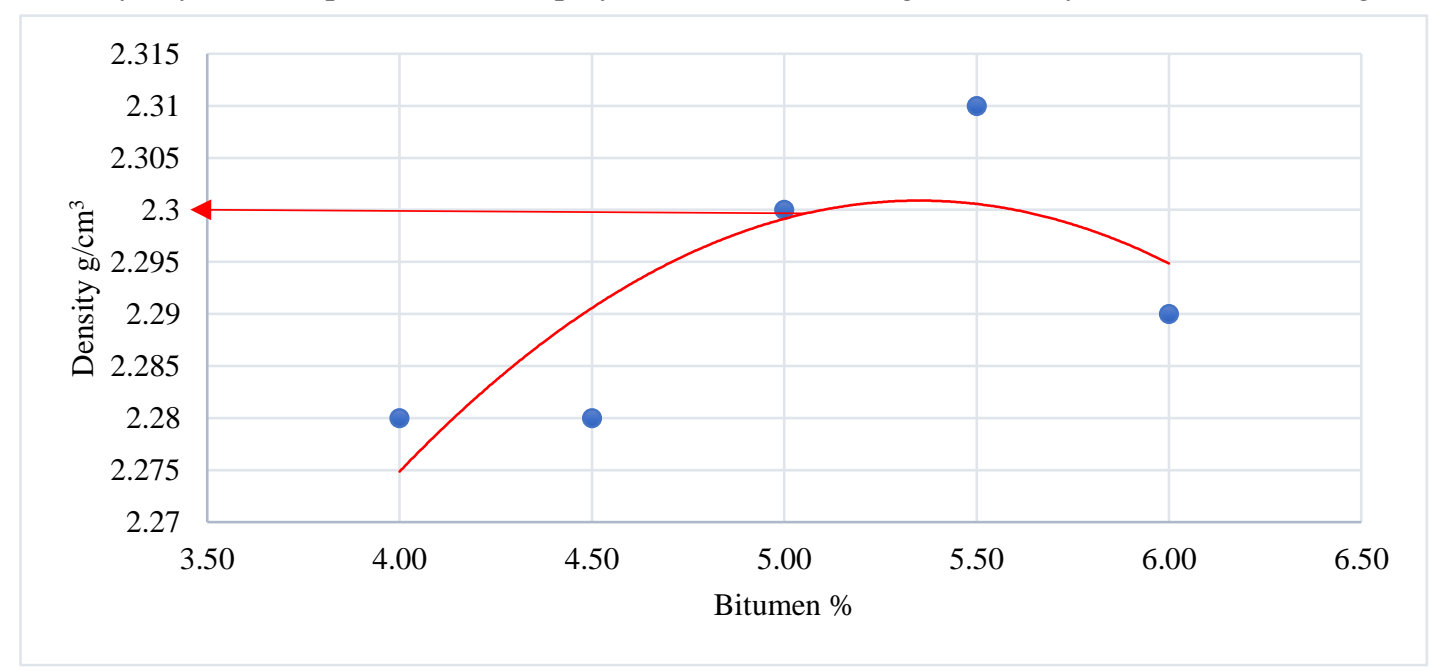

Figure 1. Density versus bitumen content for control bitumen.

\subsubsection{Voids}

The properties of VTM are considered one element to calculate the optimum bitumen content. In this study, $4 \%$ VTM showed a value of $3.91 \%$ bitumen content. The VTM value of the mix decreased with increasing bitumen content until the value of a minimum void is reached, after which no voids remain in the mix. This study showed that voids filled with bitumen for the modified bitumen using PET polymer tends to increase as the bitumen content increase. Figure 2 shows the graph of VFB versus modified bitumen content.

The results showed that voids in the total mix tend to reduce as the bitumen content increases. Figure 2 shows that the highest VTM value reached was $4.45 \%$ when added with $2 \%$ of PET polymer as the percentage of PET polymer added to increase air voids tends to be filled with bitumen, therefore as the percentage of PET polymer added $10 \%$, the VTM value reached $3.85 \%$. The properties of VTM are considered one element to calculate the optimum modified-bitumen content. In this study, the value is considered, 4\% VTM, showing a $3.85 \%$ PET polymer addition value. The VTM value of the mix decreases with increasing PET polymer content until the value of a minimum void is reached, after which no voids remain in the mix. This study has shown that the voids in the total mix of modified bitumen are relatively less than control bitumen. This means that PET polymer has helped the bitumen's viscosity properties in a way in which the aggregates have fewer voids between their particles when coated with modified bitumen. 


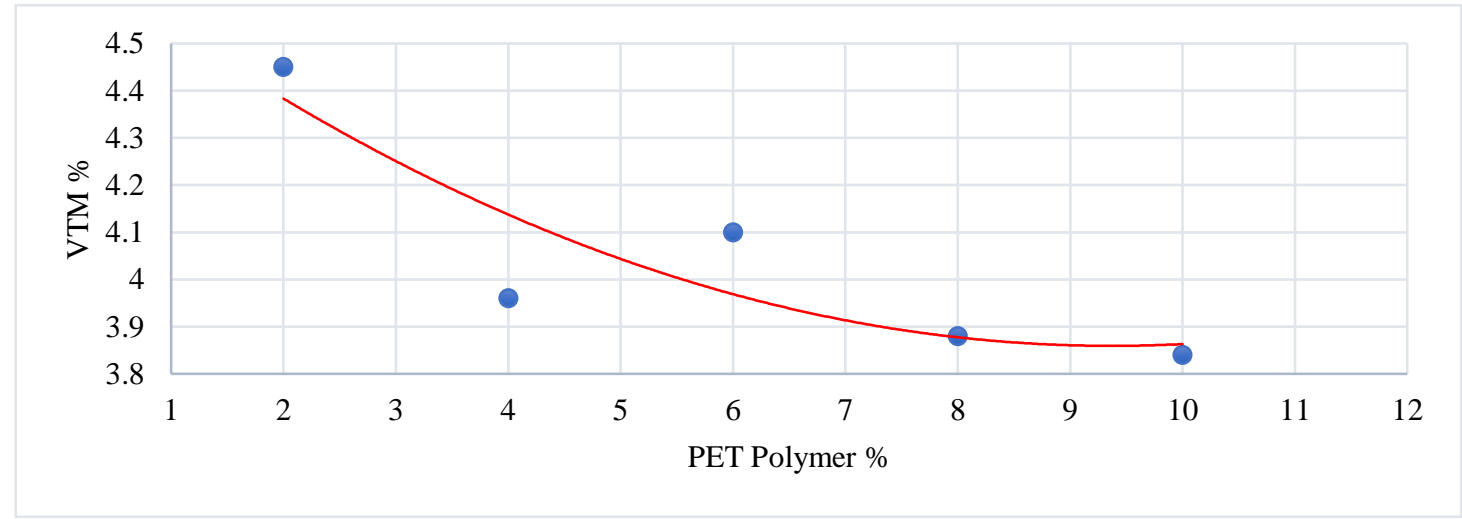

Figure 2. VTM versus modified bitumen content.

\subsubsection{Flow}

The results showed that the flow of the bituminous mix tends to increase as the bitumen content increases. Figure 3 shows the graph of flow versus bitumen content for the control sample. Figure 3 shows that the highest flow value reached was $4.48 \mathrm{~mm}$ at a bitumen content of $6 \%$. The mix's Flow value increases with increasing bitumen content until a maximum value is reached, after which the mixes tend to become softer after each addition of bitumen content. The results showed that the bituminous mix flow tends to increase as the percentage of PET polymer addition increases. Figure 4 shows the graph of flow versus modified bitumen content showed that the highest flow value reached was $4.45 \mathrm{~mm}$ at bitumen content of $10 \%$ PET Polymer addition. The mix's Flow value increases with increasing bitumen content until a maximum value is reached, after which the mixes tend to become softer after each addition of bitumen content.

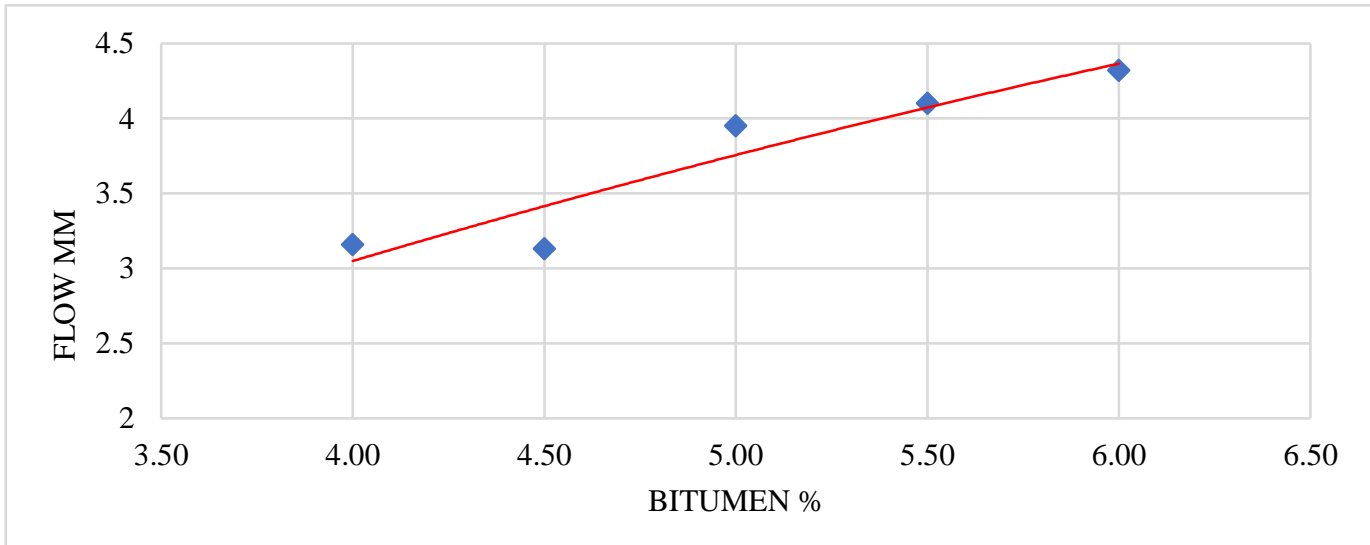

Figure 3. Flow versus bitumen content for normal bitumen.

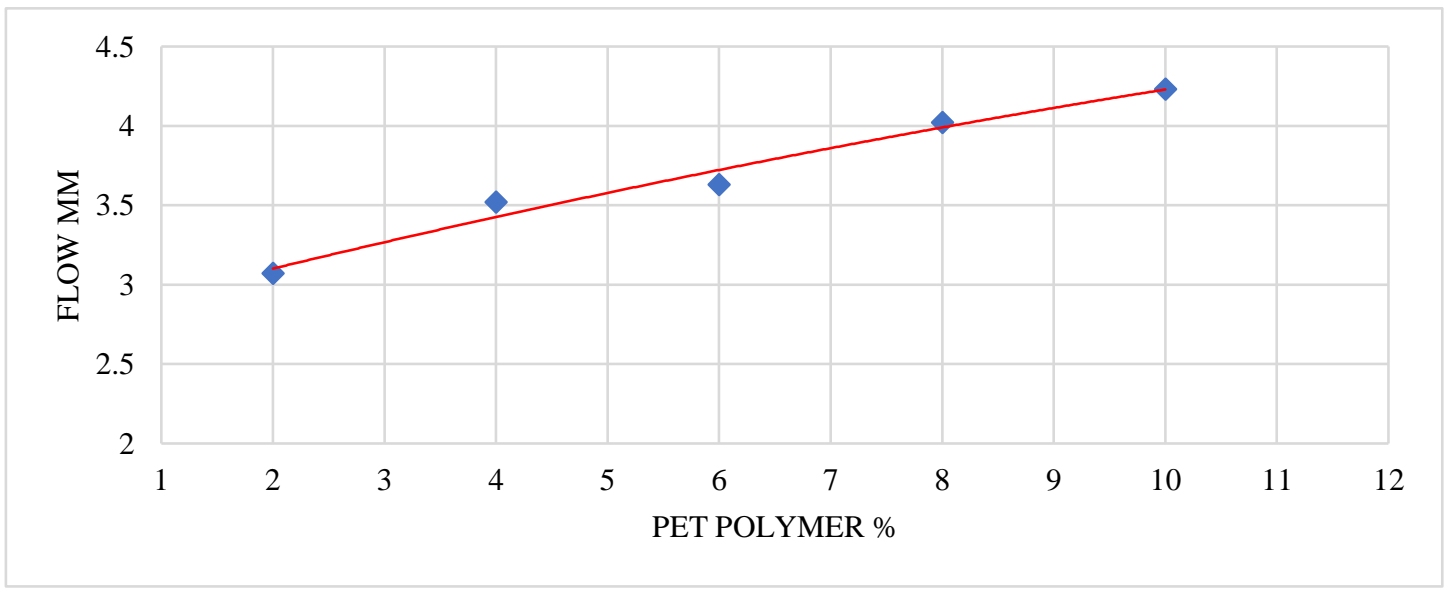

Figure 4. Flow versus modified bitumen content. 


\subsubsection{Stability}

The bituminous mixes' properties are considered one of the essential elements to calculate the Optimum Bitumen Content. The value taken to consideration is the highest peak point of the graph, which is considered the maximum stability. Figure 5 shows the graph of Marshall stability versus bitumen content for the control sample. Figure 5 showed that the highest Stability value reached was $14,060 \mathrm{~N}$ at a bitumen content of 5\%. As the bitumen content increases, the bituminous mix will reduce until it reaches $8,350 \mathrm{~N}$ at $6 \%$ bitumen Content. The results showed that the bituminous mix's stability tends to increase as the PET Polymer addition increase, then the stability starts to reduce again. Figure 6 shows the graph of Marshall stability versus modified bitumen content. Figure 6 reports that the highest Stability value reached was 14,000 N at PET Polymer addition of $8 \%$. As the percentage of PET Polymer increases, the bituminous mix's stability will start reducing, and it reached 8,500 N at $10 \%$ of PET Polymer content. The bituminous mixes' properties are considered one of the essential elements to calculate the optimum bitumen content. The value taken to consideration is the highest peak point of the graph, which is considered the maximum stability. This study showed that the addition of PET polymer to the bitumen had increased its ability against stability test. It has also made the mixes more challenging to resist high loads, this is one of the PET polymer properties, and it has high viscosity.

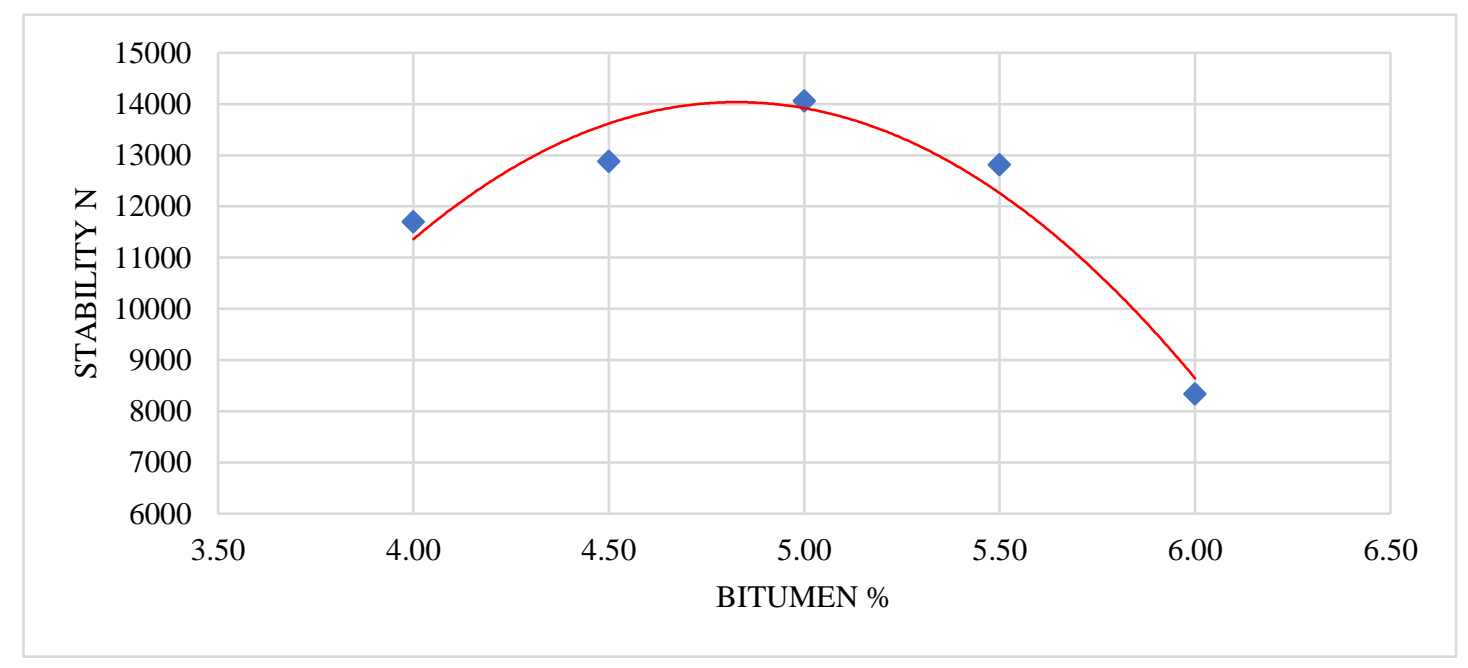

Figure 5. Marshall Stability versus bitumen content for normal bitumen.

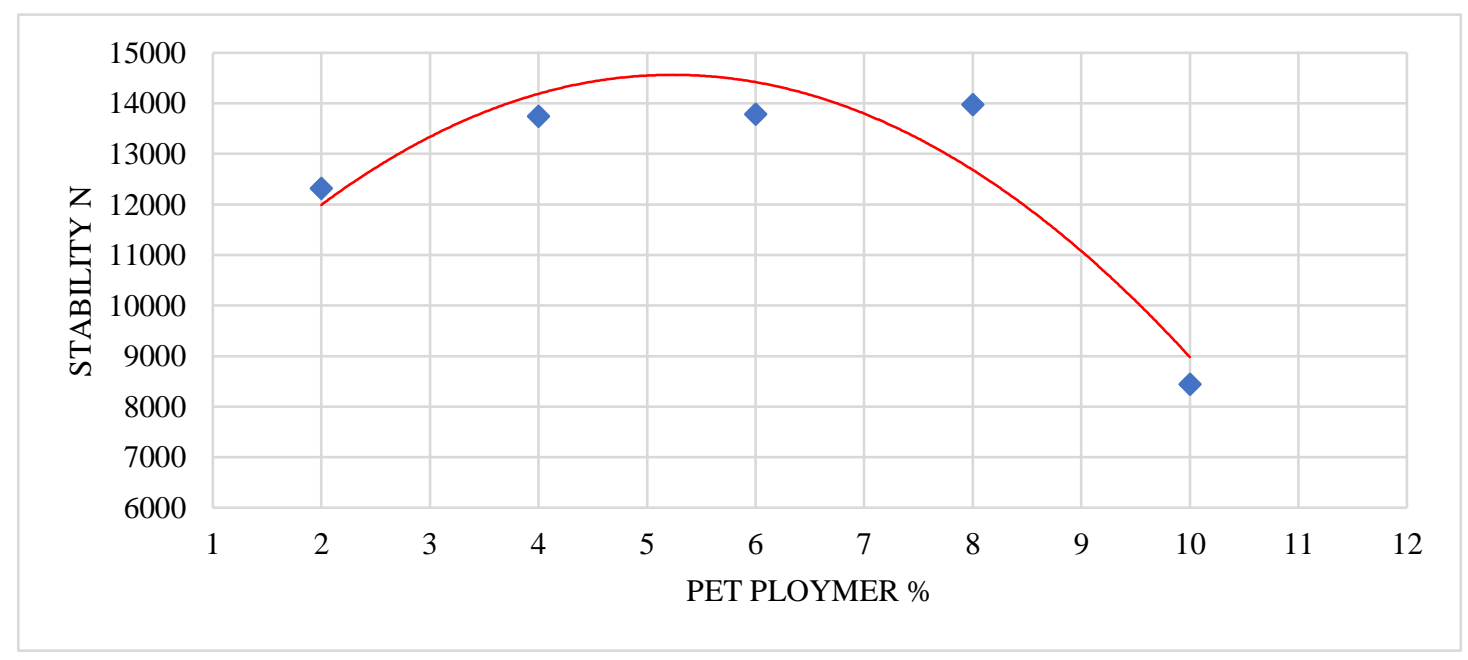

Figure 6. Stability versus modified bitumen content.

\subsubsection{Stiffness}

The results showed that the bituminous mix's stiffness tends to increase as the bitumen content increases, then the stiffness starts to reduce again. Figure 7 shows the graph of stiffness versus bitumen content for the control sample. Figure 8 reveals that the bituminous mix value's highest stiffness reached was $4,000 \mathrm{~N} / \mathrm{mm}$ at a bitumen content of $4.5 \%$. As the bitumen content increases, the bituminous mix's stiffness will start reducing till it reached $2,000 \mathrm{~N} / \mathrm{mm}$ at $6 \%$ bitumen content. The results showed that the bituminous mix's stiffness tends to 
increase as the modified bitumen content increases, then the stiffness starts to reduce again. Figure 8 showed that the bituminous mix value's highest stiffness reached was $4,200 \mathrm{~N} / \mathrm{mm}$ at PET polymer content of $4.5 \%$. As the modified bitumen content increases, the bituminous mix's stiffness will start reducing until it reached 2,250 $\mathrm{N} / \mathrm{mm}$ at $10 \%$ PET Polymer Content.

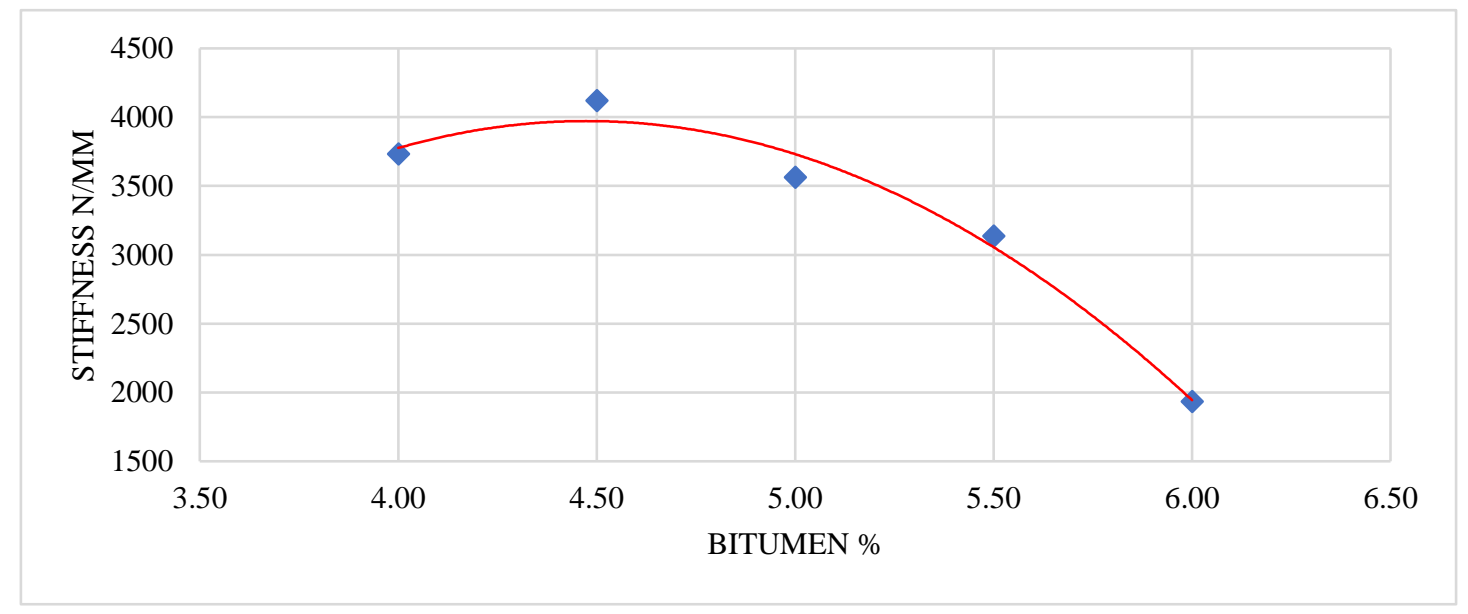

Figure 7. Stiffness stability versus bitumen content for normal bitumen.

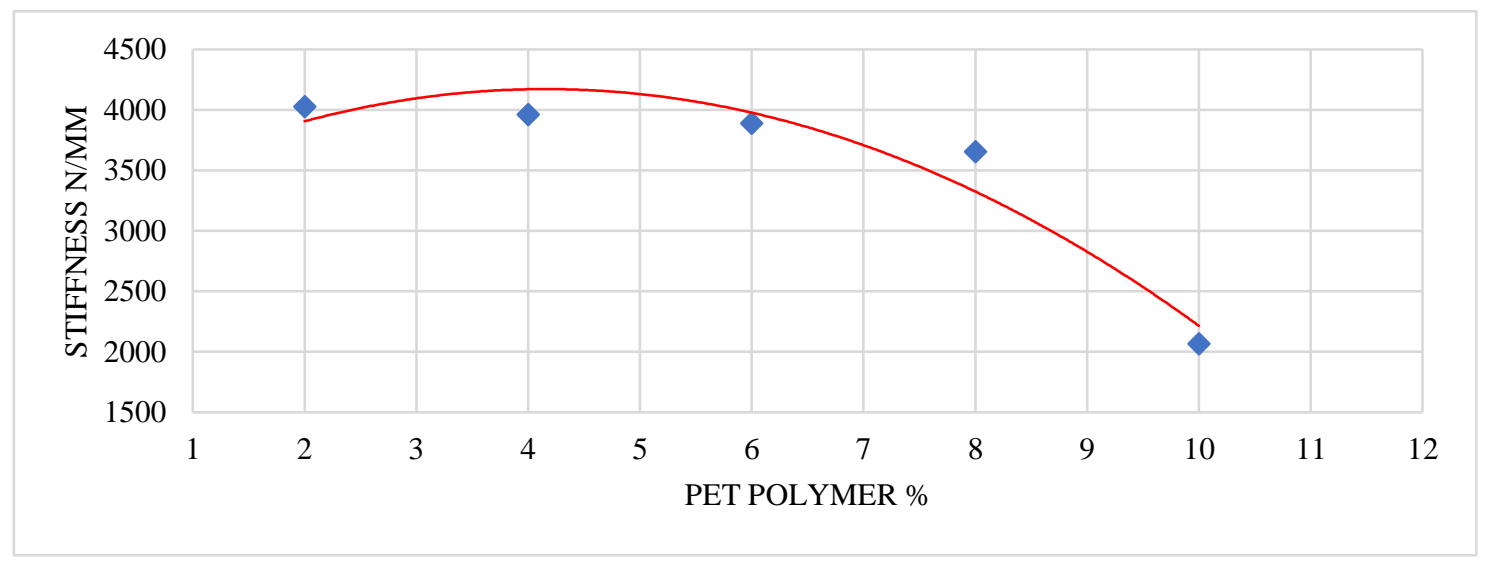

Figure 8. Stiffness versus modified bitumen content.

\section{Discussions}

The penetration test for modified bitumen using PET polymer showed less value than control bitumen. A modified bitumen improved the bitumen's viscosity in the penetration test, whereas by each percentage added, the PEN Value was decreasing. The PEN value for controlled bitumen was $81 \mathrm{~mm}$; when the addition of PP polymer started, bitumen's viscosity starts increasing till the PEN value reached 48 PEN at $10 \%$ of PET Polymer addition. This method of increasing the bitumen viscosity improves its properties in loads and temperature effects. The softening point test for all samples, including the control sample, showed that when PET Polymer is added, the temperature susceptibility increases. When the control bitumen was tested for softening point test using Ring Ball Test, the value observed was $51^{\circ} \mathrm{C}$.

In contrast, with the addition of PET polymer, the temperature susceptibility started to increase till it reached $79^{\circ} \mathrm{C}$ at $10 \%$ of PET polymer addition. The marshal test analysis using optimum bitumen content and optimum modified bitumen content for both samples showed much difference in its physical properties. These differences were caused by the addition of PET Polymer to the bitumen. The PET Polymer improves the bitumen viscosity and ability to overcome hot temperatures. Some of the improved properties are bitumen mix stability, flow, stiffness, VTM, VFB and density. The mix's Marshall stability improved using PET Polymer of $5.8 \%$ addition into $5.33 \%$ bitumen content. Both control and modified samples showed different results in its Marshall Stability test. The control bitumen had a value of 14,060 N. In contrast, and the modified bitumen had a value of $14,000 \mathrm{~N}$. These values mean that the addition of 5.8\% PET Polymer of control optimum bitumen content has improved the stability of the bitumen mixes. The modified bitumen showed a lower flow value than the control asphalt mixture, which means that the modification of bitumen using PET Polymer was successful as the asphalt mixture's viscosity increased, which led to more challenging binding between aggregates particles. 
The flow value for modified bitumen at optimum modified bitumen Content of $5.80 \%$ of PET Polymer was $3.72 \mathrm{~mm}$.

In contrast, the flow value for control bitumen at optimum bitumen content of $5.33 \%$ was $3.95 \mathrm{~mm}$. Both mixes' stiffness passed the JKR Requirements for road pavement; JKR requires that the bitumen mix not have stiffness less than 2,000 N/mm. The modified bitumen showed 4,200 N/mm at optimum modified bitumen Content of $5.80 \%$, whereas for the control mixture, the bitumen mix showed a stiffness value of $4000 \mathrm{~N} / \mathrm{mm}$ at optimum bitumen content of $5.33 \%$. This value showed that the PET Polymer mixed a stiffer property that can undertake high loads and resist higher temperature and harsh environment. The value for VTM for both bitumen, modified using PET Polymer and control bitumen, showed that PET polymer's use helped to minimise the voids in the mix. This will help the bitumen mix be stiffer with enables it to have a greater bulk density, which helps structure composition against high loads, as the bitumen mix tends to be harder where the Void in Total Mix is minimal. The study showed that normal bitumen had a value of a void of $4.9 \%$, whereas the modified bitumen using PET polymer showed a value of $3.98 \%$. The VBF values showed that PET Polymer's addition had enabled the bitumen to fill more voids the bitumen mixes as the results showed that in control bitumen mixes, the voids filled with bitumen reached $72.5 \%$ for control bitumen. When PET polymer has added, the percentage of these voids where filled bitumen increased to 74.4. This means that PET Polymer's addition helped the voids be filled more with bitumen as its viscosity is increased. The bulk density of the mixes had different values, just like all the other properties. Like the previous properties improvement, the bulk density improved using PET Polymer at a percentage of $5.80 \%$ in addition to optimum bitumen content. The control bitumen result showed that the mix had a bulk density of $2.30 \mathrm{~g} / \mathrm{cm}^{3}$, whereas the modified bitumen using PET Polymer showed an improvement to increase the mixes' bulk density to $2.31 \mathrm{~g} / \mathrm{cm}^{3}$. Table 6 confirms the result obtained to be able to compare to JKR specification.

Table 6. Comparison of results with JKR standards.

\begin{tabular}{|c|c|c|c|c|c|}
\hline \multirow{3}{*}{$\begin{array}{c}\begin{array}{c}\text { Marshall } \\
\text { Properties }\end{array} \\
\text { Stability } \\
\end{array}$} & \multirow{3}{*}{$\begin{array}{c}\text { JKR/SPJ/2008 } \\
>8,000 \mathrm{~N}\end{array}$} & \multicolumn{2}{|c|}{ Results Obtained } & \multirow{2}{*}{\multicolumn{2}{|c|}{ Remarks }} \\
\hline & & \multirow{2}{*}{$\begin{array}{r}\text { Control } \\
14,060 \mathrm{~N} \\
\end{array}$} & \multirow{2}{*}{$\begin{array}{c}\text { Modified } \\
14,000 \mathrm{~N} \\
\end{array}$} & & \\
\hline & & & & PASS & PASS \\
\hline Flow & $2-5 \mathrm{~mm}$ & $4.48 \mathrm{~mm}$ & $4.45 \mathrm{~mm}$ & PASS & PASS \\
\hline Stiffness & $>2,000 \mathrm{~N} / \mathrm{mm}$ & $4,000 \mathrm{~N} / \mathrm{mm}$ & $4,200 \mathrm{~N} / \mathrm{mm}$ & PASS & PASS \\
\hline VTM & $3 \%-5 \%$ & $4.9 \%$ & $3.98 \%$ & PASS & PASS \\
\hline VFB & $70 \%-80 \%$ & $72.5 \%$ & $74.4 \%$ & PASS & PASS \\
\hline Density & - & $2.30 \mathrm{~g} / \mathrm{cm}^{3} \quad 3$ & $2.31 \mathrm{~g} / \mathrm{cm}^{3}$ & - & - \\
\hline
\end{tabular}

\section{Conclusion}

The study concluded that control bitumen would have improvements if mixed with PET Polymer. With PET Polymer's addition, bitumen's viscosity tends to increase, enabling the mix to gain hardness and enables the asphaltic mix to have a higher resistance to the applied load. The highest viscosity was reached at $10 \%$ of PET polymer addition as it reached $48 \mathrm{PEN}$. In comparison, bitumen's temperature susceptibility started to increase with an increasing percentage of PET polymers used. This behaviour of increasing temperature susceptibility means that the addition helped modify the bitumen to overcome high temperatures, where $10 \%$ of PET polymer addition helped improve the temperature susceptibility to $79^{\circ} \mathrm{C}$. The study analysis concluded that optimum bitumen content was achieved at 5.33\%. Simultaneously, the optimum modified-bitumen content was achieved at $5.8 \%$ of PP polymer of the total weight of control optimum bitumen content. The addition of PET polymer into the mix helped the incremental increase in the mix's bulk density, which allows the mix to become denser, thus increasing its ability against high loads. Both results fulfilled the JKR Requirements, where the bulk density reached $2.30 \mathrm{~g} / \mathrm{cm} 3$ for control optimum bitumen content, and the optimum modified-bitumen content showed a higher value of 2.31 bitumen. The voids in total mix values for both control and modified samples passed JKR $3 \%-5 \%$ minimum requirements. The optimum modified-bitumen content shows a VTM value of $3.98 \%$, whereas the control optimum bitumen content showed a VTM value of 4.9\%. It Indicates that PET polymer helped use reduces the mix's VTM values to minimise the mix's voids. This means that the mix has a higher viscosity to fill the voids found in the mix.

According to JKR Standards for Flow value 2-4 mm, both samples passed the minimum requirements of JKR. The addition of PET polymer has shown a lower flow value than control bitumen, where the flow value at the optimum modified-bitumen content was $3.75 \mathrm{~mm}$. At control optimum bitumen content, the value was $3.95 \mathrm{~mm}$. It concluded that the flow value indicates that the binding between bitumen and aggregates particles has increased using PET polymer. The stability of the modified samples using PET Polymer has shown an improvement in the Marshall Stability Test. According to JKR minimum requirements for road pavement, the 
stability value should not be less than 8,000 N. The study showed that PET Polymer's addition helped raise the mix's stability to $14,500 \mathrm{~N}$ at optimum modified-bitumen Content.

In contrast, the control bitumen had a stability value of $13,100 \mathrm{~N}$ at control optimum bitumen content. The stability value shows the stiffness and hardness of the pavement. Thus, this study's objective was achieved by improving the viscosity of the binder. The stiffness values for both samples passed the minimum requirements of JKR standards. Control optimum bitumen content showed a stiffness value of 3,400 N/mm, whereas, at optimum modified-bitumen content, the stiffness value was $4,000 \mathrm{~N} / \mathrm{mm}$.

Conflicts of Interest: The authors declare no conflict of interest.

\section{References}

[1] A. Milad, N. Ezlin Ahmed Basri, M. K.Younes, H. M.Abdelsalam, and R. Atiq Abdullah Bin O.K Rahmat, 'Selecting the Affected Factors on Pavement Distress Problems Using Analytical Hierarchy Process [AHP]', International Journal of Engineering \& Technology, vol. 7, no. 2.29, p. 716, May 2018, doi: 10.14419/ijet. v7i2.29.14004.

[2] Adwan I, Milad A, Memon ZA, Widyatmoko I, Ahmat Zanuri N, Memon NA, Yusoff NIM. Asphalt Pavement Temperature Prediction Models: A Review. Applied Sciences. 2021; 11(9):3794. https://doi.org/10.3390/app11093794

[3] Ahmad, K. A., Abdullah, M. E., Hassan, N. A., Usman, N., Hassan, M. R. M., Bilema, M. A., ... \& Batari, A. (2018, April). Effect of Biobased rejuvenator on mix design, Energy consumption and GHG Emission of High RAP Mixture. In IOP Conference Series: Earth and Environmental Science (Vol. 140, No. 1, p. 012086), doi $: 10.1088 / 1755-1315 / 140 / 1 / 012086$.

[4] Ben Zair, M. M., Jakarni, F. M., Muniandy, R., \& Hassim, S. (2021). A Brief Review: Application of Recycled Polyethylene Terephthalate in Asphalt Pavement Reinforcement. Sustainability, 13(3), 1303.

[5] A. Milad, A. S. B. Ali, and N. I. M. Yusoff, 'A review of the utilisation of recycled waste material as an alternative modifier in asphalt mixtures', Civil Engineering Journal (Iran), vol. 6, no. Special Issue. Salehan Institute of Higher Education, pp. 42-60, 20-Oct-2020, doi: 10.28991/cej-2020-sp(emce)-05.

[6] Usman, K. R., Hainin, M. R., Satar, M. K. I. M., Warid, M. N. M., Usman, A., Al-Saffar, Z. H., \& Bilema, M. A. (2021). A comparative assessment of the physical and microstructural properties of waste garnet is generated from automated and manual blasting processes. Case Studies in Construction Materials, 14, e00474, doi.org/10.1016/j.cscm.2020.e00474.

[7] Bilema, M. A., Aman, M. Y., Hassan, N. A., Ahmad, K. A., Elghatas, H. M., Radwan, A. A., \& Shyaa, A. S. (2018, April). Moisture sensitivity of crumb rubber modified modifier warm mix asphalt additive for two different compaction temperatures. In IOP conference series: Earth and environmental science (Vol. 140, No. 1, p. 012072), doi: 10.1088/1755-1315/140/1/012072.

[8] A. Milad, A. M. Taib, A. G. F. Ahmeda, M. Solla, and N. I. M. Yusoff, 'A review of the use of reclaimed asphalt pavement for road paving applications', Jurnal Teknologi, 2020, doi: 10.11113/jt.v82.14320.

[9] M. Bilema, Y. Bin Aman, N. A. Hassan, Z. Al-Saffar, K. Ahmad, and K. Rogo, 'Performance of Aged Asphalt Binder Treated with Various Types of Rejuvenators', Civil Engineering Journal, vol. 7, no. 3, pp. 502-517, Mar. 2021, doi: 10.28991/cej-2021-03091669.

[10] Milad, A., Ali, A. S. B., Babalghaith, A. M., Memon, Z. A., Mashaan, N. S., \& Arafa, S. (2021). Utilisation of Waste-Based Geopolymer in Asphalt Pavement Modification and Construction; A Review. Sustainability, 13(6), 3330, doi: 10.3390/su13063330.

11] Bilema M.A.M., Aman M.Y., Ahmad K.A. (2019) Investigating the Rheological and Physical Properties for Unaged of Crumb Rubber-Modified Binders Containing Warm Mix Asphalt Additive. In: Pradhan B. (eds) GCEC 2017. GCEC 2017. Lecture Notes in Civil Engineering, vol 9. Springer, Singapore, doi.org/10.1007/ 978-981-108016-6_100M.

[12] M. A. Bilema, M. Y. Aman, N. A. Hassan, and N. F. A. Abdullah, 'Investigation on rheology and physical properties of asphalt binder blended with waste cooking oil', in IOP Conference Series: Materials Science and Engineering, 2019, vol. 527, no. 1, doi: 10.1088/1757-899X/527/1/012045

[13] A. Milad, A. G. F. Ahmeda, A. M. Taib, S. Rahmad, M. Solla, and N. I. M. Yusoff, 'A review of the feasibility of using crumb rubber derived from end-of-life tire as asphalt binder modifier', Journal of Rubber Research, 2020, doi: 10.1007/s42464-020-00050-y.

[14] M. Bilema, M. Aman, N. Hassan, M. Haloul, and S. Modibbo, 'Influence of crumb rubber size particles on moisture damage and strength of the hot mix asphalt', Materials Today: Proceedings, Jan. 2021, doi: 10.1016/j.matpr.2020.12.423.

[15] A. F. Ahmad, A. R. Razali, and I. S. M. Razelan, 'Utilisation of polyethylene terephthalate (PET) in asphalt pavement: A review', in IOP Conference Series: Materials Science and Engineering, 2017, vol. 203, no. 1, p. 012004, doi: 10.1088/1757-899X/203/1/012004. 
[16] M. Mazouz and M. Merbouh, 'The Effect of Low-Density Polyethylene Addition and Temperature on Creeprecovery Behavior of Hot Mix Asphalt', Civil Engineering Journal, vol. 5, no. 3, p. 597, Mar. 2019, doi: 10.28991/cej-2019-03091271.

[17] F. Awaja and D. Pavel, 'Recycling of PET', European Polymer Journal, vol. 41, no. 7. Pergamon, pp. 1453-1477, 01-Jul-2005, doi: 10.1016/j.eurpolymj.2005.02.005.

[18] S. Karmakar and T. K. Roy, 'Effect of Waste Plastic and Waste Tires Ash on Mechanical Behavior of Bitumen', Journal of Materials in Civil Engineering, vol. 28, no. 6, p. 04016006, Jun. 2016, doi: 10.1061/(asce)mt.19435533.0001484 .

[19] A. O. Sojobi, S. E. Nwobodo, and O. J. Aladegboye, 'Recycling of polyethylene terephthalate (PET) plastic bottle wastes in bituminous asphaltic concrete', Cogent Engineering, vol. 3, no. 1, p. 1133480, Dec. 2016, doi: 10.1080/23311916.2015.1133480.

[20] Mashaan, N. S., Rezagholilou, A., \& Nikraz, H. Waste Plastic as Additive in Asphalt Pavement Reinforcement: A review. In AAPA International Flexible Pavements Conference, 18th. 2019.

[21] M. Nobinur Rahman, M. Ahmeduzzaman, M. A. Sobhan, and T. U. Ahmed, 'Performance Evaluation of Waste Polyethylene and PVC on Hot Asphalt Mixtures', American Journal of Civil Engineering and Architecture, vol. 1, no. 5, pp. 97-102, Jul. 2013, doi: 10.12691/ajcea-1-5-2.

[22] Apurva J Chavan, 'use of plastic waste in flexible pavements, Scinapse', Apr-2013. io/papers/2189568901.

[23] A. Modarres and H. Hamedi, 'Developing laboratory fatigue and resilient modulus models for modified asphalt mixes with waste plastic bottles (PET)', Construction and Building Materials, vol. 68, pp. 259-267, Oct. 2014, doi: 10.1016/j.conbuildmat.2014.06.054.

[24] T. Baghaee Moghaddam, M. Soltani, and M. R. Karim, 'Experimental characterisation of rutting performance of Polyethylene Terephthalate modified asphalt mixtures under static and dynamic loads', Construction and Building Materials, vol. 65, pp. 487-494, Aug. 2014, doi: 10.1016/j.conbuildmat. 2014.05.006.

[25] T. Baghaee Moghaddam, M. Soltani, M. R. Karim, and H. Baaj, 'Optimisation of asphalt and modifier contents for polyethylene terephthalate modified asphalt mixtures using response surface methodology', Measurement: Journal of the International Measurement Confederation, vol. 74, pp. 159-169, Aug. 2015, doi: 10.1016/j.measurement.2015.07.012.

[26] M. E. Abdullah, N. A. Ahmad, R. P. Jaya, N. A. Hassan, H. Yaacob, and M. R. Hainin, 'Effects of Waste Plastic on the Physical and Rheological Properties of Bitumen', in IOP Conference Series: Materials Science and Engineering, 2017, vol. 204, no. 1, p. 012016, doi: 10.1088/1757-899X/204/1/012016.

[27] E. Ahmadinia, M. Zargar, M. R. Karim, M. Abdelaziz, and P. Shafigh, 'Using waste plastic bottles as additive for stone mastic asphalt', Materials and Design, vol. 32, no. 10, pp. 4844-4849, Dec. 2011, doi: 10.1016/j.matdes.2011.06.016.

[28] E. Ahmadinia, M. Zargar, M. R. Karim, M. Abdelaziz, and E. Ahmadinia, 'Performance evaluation of utilisation of waste Polyethylene Terephthalate (PET) in stone mastic asphalt', Construction and Building Materials, vol. 36, pp. 984-989, Nov. 2012, doi: 10.1016/j.conbuildmat.2012.06.015.

[29] W. M. N. W. A. Rahman and A. F. A. Wahab, 'Green pavement using recycled Polyethylene Terephthalate (PET) as partial fine aggregate replacement in modified asphalt', in Procedia Engineering, 2013, vol. 53, pp. 124-128, doi: 10.1016/j.proeng.2013.02.018.

[30] J. Y. M. Nuñez, M. D. I. Domingos, and A. L. Faxina, 'Susceptibility of low-density polyethene and polyphosphoric acid-modified asphalt binders to rutting and fatigue cracking', Construction and Building Materials, vol. 73, pp. 509-514, Oct. 2014, doi: 10.1016/j.conbuildmat.2014.10.002. 